\title{
Phytoplankton Abundance and Distribution of Fish Earthen Ponds in Lagos, Nigeria
}

\section{*1 CHUKWU, MN; ${ }^{2}$ AFOLABI, ES}

\author{
${ }^{1}$ Biology Unit, Department of Pure and Applied Sciences, Faculty of Science, National Open University of Nigeria Head Quarters, Abuja., \\ Nigeria \\ ${ }^{2}$ Department of Aquaculture, Nigerian Institute for Oceanography and Marine Research Victoria Island, Lagos, Nigeria \\ *Corresponding au E-mail: mchukwu@noun.edu.ng and ade_ife@yahoo.com
}

\begin{abstract}
The study investigated phytoplankton abundance and distribution under different pond management to determine the effect of some physicochemical parameters on the community structure of three onresearch fish earthen ponds of Nigerian Institute for Oceanography and Marine Research, Badore, Lagos. Samples were taken every week using standard procedure. Water quality parameters; temperature, dissolved oxygen, turbidity, salinity and $\mathrm{pH}$ were measured and found to be within the optimal ranges for phytoplankton productivity. Seventeen (17) phytoplankton species belonging to family Chlorophyceae, Bacillariophyceae, Cyanophyceae and Euglenophyceae were identified. Densities of the phytoplankton ranged from $01.85 \times 10^{3}$ cells L $\mathrm{L}^{-3}$ to $25.90 \times 10^{3}$ cells $\mathrm{L}^{-3}$ in the ponds; Chlorophyceae being the most abundant. Mean cell densities of the phytoplankton were significantly different $(P<0.05)$. Few phytoplankton species were present in all the Ponds. The spatial distribution of Bacillariophyceae in ponds 1, 2 and 3 were $41.7 \%, 41.7 \%$ and $16.8 \%$, while those of Euglenophyceae were 50\%, $50 \%$ and $0 \%$ respectively. Shannon Wiener diversity index was 1.263 in Pond 1, 1.265 in pond 2 and 1.078 in Pond 3. Pond 1 had the highest phytoplankton percentage $(94.11 \%)$. Correlation coefficients were calculated for abundance with $\mathrm{pH}, \mathrm{DO}$ and temperature. Abundance was positively correlated with the temperature variations and levels of DO but negatively correlated with the $\mathrm{pH}$. Results of phytoplankton abundance of the three ponds clearly showed the influences of the physicochemical factors on diversity, distribution and abundance of phytoplankton which indirectly affects aquaculture potentials.
\end{abstract}

DOI: https://dx.doi.org/10.4314/jasem.v21i7.3

COPYRIGHT: Copyright (C) 2017 Chukwu and Afolabi. This is an open access article distributed under the Creative Commons Attribution License (CCL), which permits unrestricted use, distribution, and reproduction in any medium, provided the original work is properly cited

DATES: Received 19 October 2017; received in revised form 28 November 2017; accepted 15 December 2017

Keywords: phytoplankton abundance, diversity, distribution, fish earthen ponds, physicochemical.

The plankton community comprises of the phytoplankton and zooplankton. Phytoplankton is important organisms which act as producers of the primary food supply in any aquatic ecosystem (Battish, 1992). They are the initial biological components from which energy is transferred to higher organisms through the food chain (Tiwari and Chauhan, 2006, Babatunde, 2014 and Saifullah, 2014). Phytoplankton significantly contributes to the dynamic and succession of zooplankton in aquatic ecosystems and without them the diversity and abundance of aquatic life would be impossible (Suzie, 2015). Dynamics and changes in phytoplankton biomass are the result of a complex interplay of physical, chemical and biological processes. The physicochemical and biological features largely control the plankton production and biology of the cultured organisms. Availability of nutrients also plays a key role in determining the phytoplankton population density (Grenz et al, 2002; Elliott et al, 2002). The term "Water quality" refers for the physical, chemical and biological parameters of water and directly or indirectly influences the survival and production of aquaculture species
(Kohinoor, 2000). Environmental factors in aquatic habitats include various physical properties of water such as solubility of gases and solids, penetration of light, temperature,

and density. Chemical factors such as salinity, $\mathrm{pH}$, hardness, phosphates and nitrates are also very important for growth and density of phytoplankton on which zooplankton depend (Roy, 2014). Phytoplankton species are used as indicators of water quality because their sensitivity can be a dynamic response to changes in the surrounding environment (Siddika, 2012). Qualitative and quantitative abundance of phytoplankton indicate the productive status of a water body (Chowdhury et al, 2008), thus a thorough knowledge of abundance of phytoplankton and its quality in time and space in relation to environmental conditions is a prerequisite for fish production. Several studies carried out in Lagos, Nigeria were concentrated on the taxonomic identification of different phytoplankton genera and were very confined to the specific regions of Lagos lagoon. There is dearth of information on the composition of phytoplankton in fish earthen ponds in Lagos, Nigeria. This study focuses on the 
measurement of some physicochemical parameters such as temperature, transparency, dissolved oxygen and $\mathrm{pH}$ to checklist the phytoplankton abundance and distribution in fish earthen ponds in the Nigerian Institute for Oceanography and Marine Research, Badore, Lagos.

\section{MATERIALS AND METHODS}

Study Area: Three on-farm research fish ponds in the Nigeria Institute for Oceanography and Marine Research Badore, Lagos, were selected. The station is located off Ado - Badore road and lies between $719917.527 \mathrm{mN} 566343.226 \mathrm{mE}$ and $719187.784 \mathrm{mN}$ $566933.382 \mathrm{mE}$ off the coast of Lagos (Figure 1). The sampling ponds were $50 \mathrm{~m}$ apart and underground water was the main source of water for the ponds.
The ponds were free from any shading and had adequate sunlight throughout the day. The size of the ponds, their respective capacities and culture system were shown in Table 1.

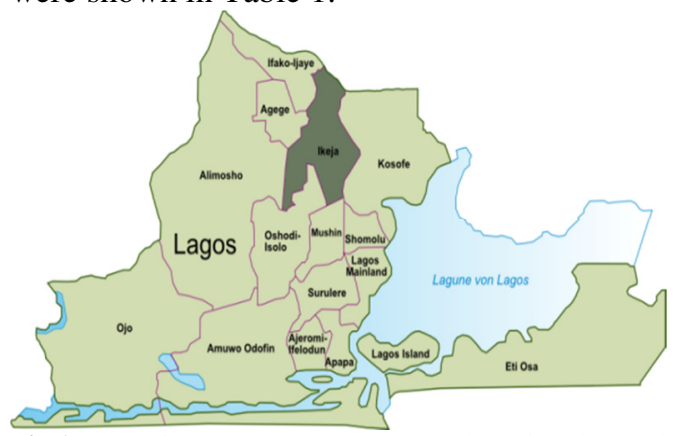

Fig 1: Map of Lagos State showing location of study area by Lagos Lagoon.

Table 1: Morphometric Characteristics of the Ponds

\begin{tabular}{llllll}
\hline PONDS & Dimensions $(\mathrm{m})$ & Sizes(Acres) & Depth $(\mathrm{m})$ & Capacity $\left(\mathrm{m}^{3}\right)$ & Culture System \\
\hline Pond 1 & $38.0 \times 32.0$ & 1.2 & 1.8 & 2188.8 & Semi-intensive \\
Pond 2 & $34.8 \times 30.5$ & 1.06 & 2.2 & 2547.4 & Semi-intensive \\
Pond 3 & $64.4 \times 51.0$ & 3.6 & 3.2 & 11823.8 & Extensive \\
\hline
\end{tabular}

Ponds 1 and 3 were stocked with Tilapia Trinocular Olympus microscope quipped with digital (Oreochromis niloticus) while Pond 2 was stocked with Tilapia (Oreochromis niloticus) and Africa mud cat fish (Clarias gariepinus).

Sampling techniques: Physicochemical and biological water quality variables were measured from the sample ponds' water. Samples were taken from each pond once a week, between 09.00 a.m. and 10.00 a.m. in duplicate for a period of eight weeks; from September to October, 2016. The $\mathrm{pH}$, salinity, dissolved oxygen, temperature and water transparency was measured in-situ. A mercury in glass thermometer was used to measure the temperature ( $\left.{ }^{\mathrm{C}} \mathrm{C}\right)$, while transparency (m) was measured with Secchi disc, $20 \mathrm{~cm}$ diameters (LaMotte-0171). Digital electronic meter (JPB-607A) was used to measure the dissolved oxygen (DO) $\left(\mathrm{mgL}^{-1}\right)$. The $\mathrm{pH}$ of samples was measured using hand held electronic probe (pH-98108) and salinity with RHW-25Brix (ATC).

Phytoplankton sampling and analysis: Samples for phytoplankton analysis were collected from four sampling points using a cone shaped, silk bolting cloth plankton net with a $50 \mathrm{ml}$ concentrate bottles. The concentrates were transferred to separately labeled $100 \mathrm{ml}$ glass jars and fixed immediately with $5 \%$ formalin, which served as a fixative. Fixed samples were allowed to settle in the Laboratory for 24 hours and the supernatant carefully discarded until concentration of $40 \mathrm{ml}$ was obtained. Phytoplankton species were examined, identified and counted using scope photo $(\times 9)$ and computer system window 2000. Drop count method as described by (Ramachandra and Malvikaa, 2007) was modified for the counting while identification of phytoplankton up to generic level was made according to (Apha, 1998).

Utilize Index and Statistical Analysis: Shannon Wiener diversity index was used to determine the plankton species composition and their diversity across the different ponds sampled. Physicochemical parameters and phytoplankton parameters were analyzed using one-way ANOVA and Post-hoc comparisons using Duncan test $(\mathrm{P}>0.05)$ while Pearson's Correlation coefficient was used to determine the association between abundance and physicochemical parameters.

\section{RESULTS AND DISCUSSION}

Most physicochemical parameters of the sampled ponds fell within the standard range and thus were favorable for the growth of phytoplankton and fish culture. The only shift from this trend is in the turbidity and $\mathrm{pH}$ of the ponds' water which were variable (Table 2 and Fig.2). Pond 3 water with high transparency of $0.89 \mathrm{~m}$ and slightly low $\mathrm{pH}(4.81 \pm$ 0.51) would be harmful to the non-tolerant phytoplankton, hence low phytoplankton abundance in the pond.

There is no significant difference in the average water air temperature and dissolved oxygen (DO) 
values between the ponds. Significant difference was however found in the $\mathrm{pH}$ values.

Table 2: Water quality parameters (Means \pm SEM) of the ponds

\begin{tabular}{llll}
\hline PARAMETERS & POND 1 & POND 2 & POND 3 \\
\hline Water temperature $\left({ }^{0} \mathrm{C}\right)$ & $27.06 \pm 0.03$ & $27.18 \pm 0.01$ & $27.25 \pm 0.02$ \\
Air Temperature $\left({ }^{0} \mathrm{C}\right)$ & $28.50 \pm 1.84$ & $28.50 \pm 01.84$ & $28.50 \pm 1.84$ \\
Dissolved Oxygen $\left(\mathrm{mgL}^{-1}\right)$ & $7.4 \pm 0.10$ & $7.52 \pm 0.14$ & $6.40 \pm 0.24$ \\
Transparency $(\mathrm{m})$ & $0.48 \pm 0.05$ & $0.49 \pm 0.04$ & $0.89 \pm 0.09$ \\
$\mathrm{pH}$ & $7.09 \pm 0.25$ & $7.16 \pm 0.27$ & $4.81 \pm 0.51$ \\
\hline 35 \\
30 \\
25 \\
20 \\
$15-1$ \\
$10-$ Water Temp.
\end{tabular}

Fig 2: Physico-chemical parameters in the ponds. Values shown = Mean \pm SEM
Phytoplankton composition of the four families; Cyanophyceae, Cyanophyceae, Bacillariophyceae and Euglenophyceae identified were shown in Table 3. The Chlorophyceae was the most abundant, followed by Bacillariophyceae, Cyanophyceae and Euglenophyceae in ponds 1 and 2. The total number of genera per pond varied from 13 to 16 . Pond 1 had the highest number of genera (16), while the least number of genera (13) was recorded in pond 3. It was obvious that pond 1 had more phytoplankton $(94.11 \%)$ than pond $2(88.23 \%)$ and pond 3 (41.17\%). Six phytoplankton genera were constant (frequency of occurrence 1) in all the Ponds. Phytoplankton abundance was in the order

Bacillariophyceae $>$ Chlorophyceae $>$ Cyanophyceae $>E$ uglenophyceae. Shanon-Wiener's index $\left(\mathrm{H}^{\prime}\right)$ was 1.263 in Pond $1,1.265$ in pond 2 and 1.078 in Pond 3 . The order of diversity is thus: $\mathrm{P} 2>\mathrm{P} 1>\mathrm{P} 3$ (Table 3 ). This is in agreement with the findings of Adeogun $e t$ $a l, 2005$ that blue algae, green algae and diatoms dominate the tropical lakes.

Table 3: Percentage distribution, species richness and diversity of phytoplankton in the ponds

\begin{tabular}{|c|c|c|c|c|c|c|}
\hline Parameters & Phytoplankton family & Genera & Pond 1 & Pond 2 & Pond 3 & $\begin{array}{l}\text { Frequency of } \\
\text { Occurrence }\end{array}$ \\
\hline & Bacillariophyceae & $\begin{array}{l}\text { Taballaria } \\
\text { Asterionella } \\
\text { Cyclotella } \\
\text { Surrirella } \\
\text { Navicula }\end{array}$ & $\begin{array}{l}x x x \\
x x \\
x x \\
x x \\
x x x\end{array}$ & $\begin{array}{l}x x \\
x x \\
x x \\
x \\
x x\end{array}$ & $\begin{array}{l}x \\
\mathrm{~A} \\
\times x \\
\mathrm{~A} \\
\mathrm{~A}\end{array}$ & $\begin{array}{l}1 \\
0.67 \\
1 \\
0.67 \\
0.67\end{array}$ \\
\hline & Cyanophyceae & $\begin{array}{l}\text { Microcystis } \\
\text { Gomphospaeria } \\
\text { Anabaena } \\
\text { Oscillatoria } \\
\text { Aphanocapsa }\end{array}$ & $\begin{array}{l}x x \\
x \\
x x x \\
x x \\
x\end{array}$ & $\begin{array}{l}x \times \\
x \times \\
x \times x \\
x \times \\
a\end{array}$ & $\begin{array}{l}\times \\
\mathrm{A} \\
\times x \\
\mathrm{~A} \\
\mathrm{~A}\end{array}$ & $\begin{array}{l}1 \\
0.67 \\
1 \\
6.67 \\
0.33\end{array}$ \\
\hline & 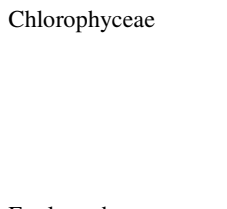 & $\begin{array}{l}\text { Ulothrix } \\
\text { Oocystis } \\
\text { Pediastrum } \\
\text { Scenedesmus } \\
\text { Chlorella } \\
\text { Actinastrum } \\
6\end{array}$ & $\begin{array}{l}x \times \\
x \times x \\
a \\
x \times x \\
x \times x \\
x \\
5\end{array}$ & $\begin{array}{l}x \times \\
x \times x \\
x \\
x \times x \\
x \times x \\
a \\
5\end{array}$ & $\begin{array}{l}\mathrm{A} \\
\mathrm{A} \\
\times \times \\
\times x \\
\times \\
\mathrm{A} \\
3\end{array}$ & $\begin{array}{l}0.67 \\
0.67 \\
0.67 \\
1 \\
1 \\
0.33\end{array}$ \\
\hline & Euglenophyceae & Euglena & $x \times$ & $x \times$ & A & 0.67 \\
\hline Number of genera/pond & & 17 & 16 & 15 & 7 & \\
\hline Percentage distribution of species (\%) & $\begin{array}{l}\text { Bacillariophyceae } \\
\text { Cyanophyceae } \\
\text { Chlorophyceae } \\
\text { Euglenophyceae }\end{array}$ & & $\begin{array}{l}100 \\
100 \\
83.33 \\
100\end{array}$ & $\begin{array}{l}100 \\
80 \\
83.33 \\
100\end{array}$ & $\begin{array}{l}40 \\
40 \\
50 \\
0\end{array}$ & \\
\hline Spatial distribution of species (\%) & $\begin{array}{l}\text { Bacillariophyceae } \\
\text { Cyanophyceae } \\
\text { Chlorophyceae } \\
\text { Euglenophyceae }\end{array}$ & & $\begin{array}{l}41.7 \\
45.5 \\
38.4 \\
50\end{array}$ & $\begin{array}{l}41.7 \\
36.3 \\
38.4 \\
50\end{array}$ & $\begin{array}{l}16.8 \\
18.2 \\
23.1 \\
0\end{array}$ & \\
\hline $\begin{array}{l}\text { Percentage composition }(\%) \\
\text { Shannon-Wiener's index }\left(\mathrm{H}^{\prime}\right)\end{array}$ & $\begin{array}{l}\text { Bacillariophyceae } \\
\text { Cyanophyceae } \\
\text { Chlorophyceae } \\
\text { Euglenophyceae }\end{array}$ & & $\begin{array}{l}31.25 \\
31.25 \\
31.25 \\
6.25 \\
94.11 \\
1.263\end{array}$ & $\begin{array}{l}33.33 \\
26.67 \\
33.33 \\
6.67 \\
88.23 \\
1.265\end{array}$ & $\begin{array}{l}28.57 \\
28.57 \\
42.85 \\
0 \\
41.17 \\
1.078\end{array}$ & \\
\hline
\end{tabular}




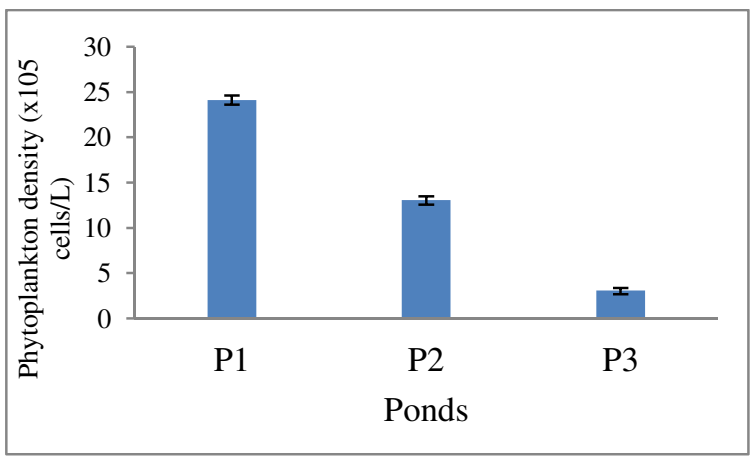

Fig 3: Cell densities of phytoplankton in the ponds. Values shown $=$ Mean \pm SE

Phytoplankton density was variable among the ponds investigated. The highest total density of phytoplankton was observed in pond 1 . The lowest phytoplankton density in pond 3 was due to the treatment of ponds 1 and 2 with manure which influenced their $\mathrm{pH}$ and nutrient availability thus increasing the phytoplankton communities. Shannon -Weaver species diversity index was relatively high in ponds 2 and 1 and low in pond 3 (Table 3 ). This portrayed more species diversity in ponds 1 and 2 compared to pond 3; order of diversity being $\mathrm{P} 2>\mathrm{P} 1>\mathrm{P} 3$ (Table 4 ). There was a significant difference in the mean phytoplankton density of the three ponds $(\mathrm{P}<0.05)$. Similar observations were made by (Elliott et al, 2002) in various pond habitats.
Table 4: Variations in mean abundance of total phytoplankton (x $10^{3}$ cells $1^{-3}$ ) during the study period

\begin{tabular}{llll}
\hline Week & Pond 1 & Pond 2 & Pond 3 \\
\hline $\mathbf{1}$ & $23.05 \pm 0.95^{\mathbf{c}}$ & $12.00 \pm 0.35^{\mathbf{b}}$ & $3.07 \pm 0.17^{\mathbf{a}}$ \\
$\mathbf{2}$ & $25.90 \pm 1.30^{\mathbf{c}}$ & $14.00 \pm 0.20^{\mathbf{b}}$ & $3.16 \pm 0.14^{\mathbf{a}}$ \\
$\mathbf{3}$ & $22.70 \pm 0.40^{\mathbf{c}}$ & $11.90 \pm 0.40^{\mathbf{b}}$ & $2.30 \pm 0.10^{\mathbf{a}}$ \\
$\mathbf{4}$ & $22.39 \pm 0.01^{\mathbf{c}}$ & $11.39 \pm 0.01^{\mathbf{b}}$ & $1.89 \pm 0.01^{\mathbf{a}}$ \\
$\mathbf{5}$ & $22.60 \pm 0.10^{\mathbf{c}}$ & $12.60 \pm 0.10^{\mathbf{b}}$ & $1.50 \pm 0.40^{\mathbf{a}}$ \\
$\mathbf{6}$ & $25.72 \pm 0.10^{\mathbf{c}}$ & $14.10 \pm 0.20^{\mathbf{b}}$ & $3.40 \pm 0.20^{\mathbf{a}}$ \\
$\mathbf{7}$ & $25.30 \pm 0.70^{\mathbf{c}}$ & $14.60 \pm 0.45^{\mathbf{b}}$ & $4.24 \pm 0.06^{\mathbf{a}}$ \\
$\mathbf{8}$ & $25.32 \pm 0.78^{\mathbf{c}}$ & $14.57 \pm 0.52^{\mathbf{b}}$ & $4.50 \pm 0.15^{\mathbf{a}}$ \\
Total mean density & $24.12 \pm 0.42^{\mathbf{c}}$ & $13.26 \pm 0.36^{\mathbf{b}}$ & $3.01 \pm 0.26^{\mathbf{a}}$ \\
\hline
\end{tabular}

The effect of the negative correlation between phytoplankton abundance and $\mathrm{pH}$ range in the ponds characterized with acidic water resulted in low phytoplankton density and diversification (Table 5). This is in agreement with the findings of (Asha, 2015) that water resources with strong acidic water may sustain only acidic species. The spatial distribution (\%) varied for the family of Cyanophyceae (Fig 4a-c). The spatial distribution for Bacillariophyceae in ponds 1,2 and 3 were $41.7 \%, 41.7 \%$ and $16.8 \%$ respectively while those for the Euglenophyceae were $50 \%, 50 \%$ and $0 \%$ in ponds 1, 2 and 3 respectively (Fig.4a-c). Pearson's correlation coefficients showed that water transparency is inversely proportional to the abundance of phytoplankton; hence an increase in plankton will reduce transparency of water and increase avail ample food availability to fishes for high productivity
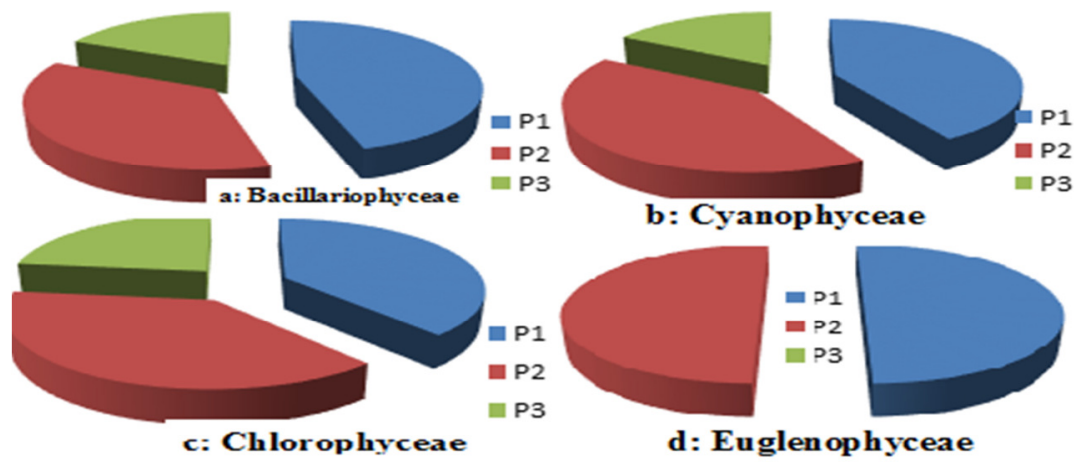

d: Euglenophyceae

Fig 4a-d: Spatial distribution of phytoplankton in Pond 1 (P1), Pond 2 (P2) and Pond 3 (P3)

Table 5: Pearson Correlation Matrix between Physicochemical Parameters and Phytoplankton Densities of the three Earthen Fish Ponds KEYS: Pond (P1, P2, P3), Temperature (T), Dissolved Oxygen (DO), pH

\begin{tabular}{|l|l|l|l|l|l|l|l|l|l|l|l|l|}
\hline & P1 & P2 & P3 & T1 & T2 & T3 & DO1 & DO2 & DO3 & pH1 & pH2 & pH3 \\
\hline P1 & 1 & & & 0.528 & & & 0.870 & & & -0.726 & & \\
\hline P2 & & 1 & & & 0.647 & & & 0.690 & & & -1.081 & \\
\hline P3 & & & 1 & & & 0.942 & & & 0.875 & & & -0.168 \\
\hline T1 & 0.528 & & & 1 & & & 0.716 & & & -0.1866 & & \\
\hline T2 & & 0.647 & & & 1 & & & 0.942 & & & -0.018 & \\
\hline T3 & & & 0.942 & & & 1 & & & 0.479 & & & -0.706 \\
\hline D01 & 0.870 & & & 0.716 & & & 1 & & & -0.692 & & \\
\hline DO2 & & 0.690 & & & 0.942 & & & 1 & & & -0.443 & \\
\hline DO3 & & & 0.875 & & & 0.479 & & & 1 & & & -0.249 \\
\hline pH1 & -0.726 & & & -0.186 & & & -0.702 & & & 1 & & \\
\hline pH2 & & -1.081 & & & -0.436 & & & -0.443 & & & 1 & \\
\hline pH3 & & & -0.168 & & & -0.706 & & & -0.249 & & & 1 \\
\hline
\end{tabular}


Conclusion: It is evident that the occurrence and abundance of phytoplankton species in these ponds were closely related to their physicochemical characteristics. The physicochemical parameters influenced the distribution and abundance of the phytoplankton and zooplankton. In view of the quantity, quality and the phytoplankton abundance and distribution in the ponds; there is a need to employ a measure to improve the quality of the ponds' water for sustainability of the cultured fishes.

\section{REFERENCES}

Adeogun, OA, Fafioye, OO, Olaleye, BA Ngobili, GO. (2005). The relationship between some physicochemical parameters and plankton composition on fish production in ponds. In the 19th annual conference of the Fisheries Society of Nigeria, (FISON), Ilorin, Nigeria.

APHA-AWWA-WEF, (1998). Standard methods for the examination of water and wastewater. 20th edition, Washington: American Public Health Association, America Water Works Association, Water Environmental Federation.

Asha, MS. (2015). Effect of Water Quality on Phytoplankton Abundance in Selected Ponds of Nedumangad Block Panchayat, Kerala. Emer Life Sci. Res. 1(2): 35-4

Babatunde, MM. (2014) Variations of phytoplankton abundance and species composition in KudiddiffiKubanni stream, Hanwa-Makera, Zaria, Nigeria. Implication for water quality. Int. J. Ad. Sci Technic Res.. 6 (4): 415-424

Battish, SK. (1992). Freshwater zooplanktons of India. Oxford and IBH publishing co. Ltd., New Delhi

Chowdhury, MMR, Shahjahan M, Rahman, MS; Sadiqul Islam M. (2008). Duckweed (Lemna minor) as supplementary feed in monoculture of Nile tilapia, Oreochromis niloticus. J. Fish. Aquatic Sci. 3: 54-59.

Elliott, JA, Irish, AE and Reynolds, CS. (2002). Predicting the spatial dominance of phytoplankton in a light limited and incompletely mixed eutrophic water column using the PROTECH model. Freshw. Biol. 47 (3): 433-440.

Grenz, C, Cloern, JE and Hager, SW. (2000). Dynamics of nutrient cycling and related benthic nutrient and oxygen fluxes during a spring phytoplankton bloom in South San Francisco Bay (USA). Mar. Ecol. Prog. Ser. 197: 67-80.

Hossain, MY, Jasmine, S, Ibrahim, AH, Ahmed, ZF, Ohtomi, J and Fulanda, B. (2007). A preliminary observation on water quality and plankton of an Earthen fish pond in Bangladesh: Recommendations for future studies. Pak. J. Biol. Sci. 10: 868-873.

Kohinoor, AHM. (2000). Development of culture technology of three small indigenous fish mola (Amblypharyngodon mola), punti (Puntius sophare) and chela (Chela cucius) with notes on some aspects of their biology. Ph.D. Thesis, Department of Fisheries Management, BAU, Mymensingh.

Okoro, CB. (2014). Study on optimum protein requirements of fingerlings of Maglops atlanticus under different culture system. PhD Thesis, Michael Okpara University.

Ramachandra et al. (2014). Ecological Assessment of Lentic Water Bodies of Banglore. January 2007 Environmental Information System [ENVIS] Centre for Ecological Sciences, Indian Institute of Science, Bangalore - 560012, INDIA ENVIS Technical Report; 25: 78

Roy, K. (2014). Ecological Dynamics and Hydrobiological Correlations In Freshwater Ponds Recent Researches and Application. Int.J. Environ Biol. Universal Res. Publications. 4 (2):112-118.

Siddika, F. (2012). Abundance of Plankton Population Densities In Relation To Bottom Soil Textural Types in Aquaculture Pondsint. J. Agril. Res. Innov. Tech. 2 (1): 56-61.

Saifullah, ASM. Abu Hena, MK, Idris, MH, Halimah, AR and Johan, I. (2014). Diversity of phytoplankton from mangrove Estuaries of Sarawak, Malaysia. World Appl. Sci. J.; 31: 915924

Suzie, KZ. (2015). Study of Phytoplankton in Relation To Physicochemical Properties of a Drainage in Kakuri Industrial Base Settlement In Kaduna, Nigeria. Sci.ence World J.; 10 (2):.6-12

Tiwari, A, Chauhan, SVS. (2006). Seasonal phytoplanktonic diversity of Kitham Lake, Agra. J. Environ. Biol. 27: 35-38. 